\title{
私の診療とエ夫 III
}

\section{ニトログリセリン軟高による裂肍の治療 （高濃度少量自己塗布法）}

\author{
土屋 和弘 \\ 草薙土屋外科医院
}

索引用語：裂肛，ニトログリセリン軟高

\section{1.はじめに}

肛門内括約筋の過緊張が肛門管内圧の上昇と局所 の血流減少をもたらし肛門管上皮の潰場形成，さら に裂肛へと進展するのは周知のことである。この括 約筋の過緊張，㾏攣を減少させる方法として側方皮 下内括約筋切開術や用手的拡張術が施行され，安定 した治療成績が得られている。

しかし手術を望まない患者や，これから出産を考 えなければならない若年女性，また急性期の疼痛軽 減が必要な例には chemicalsphincterotomy として のニトログリセリン軟膏処置が有用である.

用いられるニトログリセリン軟高の濃度は文献上 の報告では $0.2 \% ， 0.5 \%$ が多く，1日の総量も $2 \mathrm{mg}$ から $20 \mathrm{mg}$ とされている. しかし市販されている二 トログリセリン軟亮剤は $2 \%$ 剂であり，各医療機関 で希釈して使用しているのが現状である.

今回私は外来患者に $2 \%$ 軟膏丳を希釈せずそのま ま $2 \mathrm{mg}$ 相当量を直接,肛門周囲皮膚組織に塗布させ 特別な合併症もなく期待される成績が得られたの で，その方法について紹介する。

\section{2. 対 象}

平成 10 年 8 月から平成 13 年 9 月までに外来にて ニトログリセリン軟膏を投与した急性裂肛 16 例, 慢 性裂肛 6 例, 計 22 例を対象とした. 性別では男性 11 例，女性 11 例で，年齡別では 20 歳代 5 例， 30 歳代 9 例, 40 歳代 2 例, 50 歳代 1 例, 60 歳代 5 例であっ た。経過観察は治療後最長 3 年から最短 2 カ月で

Treatment of anal fissure with Nitroglycerin ointment: Anal loca application with $2 \%$ Nitroglycerin ointment by selffinger Dept. of Surgery, Kusanagi-Tsuchiya Surgical Clinic : K. Tsuchiya
あった. 全例入院を要せず, 外来での治療であった.

3. 方 法

$2 \%$ ニトログリセリン軟亳剂（三和化学 K.K. 製バ ソレーター軟膏）をチューブより $2 \mathrm{~mm}$ 押し出した 内容量が約 $0.1 \mathrm{~g}$ であり，これを患者の示指により肛 門周囲皮膚に塗布させるものである。この際肛門管 内，直腸粘膜への塗布は軟膏の吸収が速すぎること もあり塗布は肛門周囲の皮膚にとどめておくことが 必要である。また投薬前に医師がチューブより $0.1 \mathrm{~g}$ 容量を押し出して，患者がその量を正確に認識出来 る様に示した。またもし患者が使用時軟膏を過剩に 押し出した時は，それを拭き取り改めて $0.1 \mathrm{~g}$ を出し て塗布する様に指導した。塗布は症状消失まで行っ た。

22 例中 21 例は 1 日 1 回 (排便後または就葠前) 塗 布し，1例のみ 1 日 2 回塗布していた.

\section{4. 結 果}

結果を表 1 に示した。急性期裂肛症例では 3 日以 内に症状の消失したものは男性 6 例中 4 例, 女性 10 例中 1 例, 3 日五ら 1 週以内のもの男性 2 例，女性 3 例, 1 2 週以内のもの女性 4例, 2 3 週以内のもの 女性 2 例であった．再発を認めたものは男性 0 例, 女性 4 例であった．再発したものを無効とすると有 効率男性 100\%，女性 60\% であった（表 1-1）.

慢性裂肛症例では症状消失が一週間以内であった もの 2 例, 3 週間以内 2 例, 2 力月以内の症例は 1 例 であった。これらのうち再発を認めないものは 3 例 であり有效率 $60 \%$ であった. 1 例は頭痛のため使用 を中止した。

再発例は急性，慢性裂肛症例とも数力月に 1 度程 
表 1-1 急性裂肛症例の結果

\begin{tabular}{|c|c|c|c|c|}
\hline 症例数 & $\begin{array}{c}\text { 症状消失 } \\
\text { 一週間以内の例数 }\end{array}$ & $\begin{array}{c}\text { 㾬状消失 } \\
1 \sim 4 \text { 週以内の例数 }\end{array}$ & 再発例数 & 有効率 \\
\hline 男 & 6 & 0 & 0 & $100 \%$ \\
\hline 女 10 & 4 & 6 & 4 & $60 \%$ \\
\hline
\end{tabular}

表 1-2 慢性裂肍症例の結果

\begin{tabular}{|c|c|c|c|c|}
\hline 症例数 & $\begin{array}{c}\text { 症状消失 } \\
\text { 一僴以内の例数 }\end{array}$ & $\begin{array}{c}\text { 症状消失 } \\
1 \sim 8 \text { 週以内例数 }\end{array}$ & 再発例数 & 有効率 \\
\hline 5 & 2 & 3 & 2 & $60 \%$ \\
\hline
\end{tabular}

度の再発で，その都度ニトログリセリン軟膏剤を塗 布して軽快しており手術には至っていない。

合併症としては軽度の頭痛の出現が男女共 11 例 中 3 例に認められその発生率は $27 \%$ であった. 6 例中 1 例は叙布を中止したが 5 例は治療継続が可能 であった．年齢でみると若年層の頭痛出現が多く認 められ男性は 20 歳代, 女性は 35 歳までの症例で あった。薬剤塗布による局所の刺激感, 排便に関す る障害は認められなかった。

\section{5. 考察}

内外括約筋の収縮を抑制する神経伝達物質である NO の供給体であるニトログリセリン郕は chemical sphincterotomy としての機能を発揮する.

裂肛に対するこトログリセリン軟高による治療報 告は外国文献では良くみられるが，我国では服部の 報告をみるに過ぎない.服部は急性例 6 例中 6 例に， 慢性例 12 例中 8 例に有効な結果を得ている.その使 用法は $2 \%$ ニトログリセリン軟膏を白色ワセリンで $0.5 \%$ に希釈し1日 2 4 回計 $5 \mathrm{mg} \sim 20 \mathrm{mg}$ を使用し たものである。

今回私の使用した方法は $2 \%$ の高濃度㓮を 1 日1
回, 1 回量 $2 \mathrm{mg}$ の使用のみであり, 軟衰剂を希釈す ることも不要であり，1日1回の塗布で有効であっ た。これは内外括約筋の過緊張を一日一度でも解除 することにより治癒機転が㗢くためと考えられた。 $2 \%$ 軟高剂を $0.1 \mathrm{~g}$ ，直接肛門周囲に塗布する簡便な 万法により，手術が回避出来れば患者にとって大い なる恩恵であり，医療経済上でも有益なことと思わ れる。

本論文の要旨は平成 13 年 11 月 17 日第 13 回東海肛門疾 患愳談会に於いて発表した。いろいろと御教示戴きました木 島病院服部和伸先生に感謝申し上げます。また御校閲戴きま した胃腸科・肛門科松田病院 (浜松市) 松田保秀先生に深謝 申し上げます。

\section{文献}

1）服部和伸，中島久幸：ニトログリセリン軟高による裂肛 の治療. 臨外 52:521-523, 1997

(2001年12月 5 日受付)

(特別揭載) 